\title{
Partisipasi Masyarakat Dalam Pengembangan Homestay Di Desa Wisata Pangsan Kabupaten Badung
}

\author{
Nyoman Arto Suprapto ${ }^{1)}$; Moh. Agus Sutiarso ${ }^{2)}$; Agus Suryanto ${ }^{3)}$ \\ ${ }^{1)}$ Dosen DIV Manajemen Pariwisata, STPBI \\ ${ }^{2)}$ Dosen DIV Manajemen Pariwisata, STPBI \\ 3) Mahasiswa DIV Manajemen Pariwisata, STPBI \\ E-mail: artosuprapto@stpbi.ac.id
}

\begin{abstract}
ABSTRAK
Desa Pangsan adalah salah satu Desa Wisata yang terletak di Kecamatan Petang Kabupaten Badung. Kondisi alam dan kegiatan pertanian menjadi salah satu potensi utama pengembangan Desa Pangsan sebagai salah satu Destinasi Wisata di Kabupaten Badung. Selain daya tarik wisata, infrastruktur pendukung pariwisata adalah hal wajib yang harus disediakan pada destinasi ini. Penelitian ini dilakukan untuk mengetahui persepsi masyarakat di Desa Wisata Pangsan terhadap pengembangan homestay, partisipasi apa saja yang sudah dilakukan masyarakat dalam mengembangkan homestay di Desa Wisata Pangsan dan kendala apa saja yang ditemui oleh masyarakat dalam berpartisipasi.

Teknik pengumpulan data yang digunakan dalam penelitian ini adalah observasi, wawancara terstruktur, dokumentasi dan studi pustaka. Teknik analisis yang digunakan adalah analisis mix method yaitu bentuk analisis yang menggabungkan antara analisi kualitatif dan juga analisis kuantitatif. Hasil penelitian menunjukkan bahwa masyarakat di Desa Wisata Pangsan menyambut dengan baik keberadaan homestay karena dianggap memberikan peluang ekonomi yang lebih baik dan memberikan dampak yang positif terhadap kondisi lingkungan di Desa Wisata Pangsan. Bentuk partisipasi masyarakat yang dilakukan di Desa Wisata Pangsan berupa partisipasi langsung dan partisipasi tidak langsung. Bentuk partisipasi langsung yang dilakukan masyarakat dalam pengembangan homestay di Desa Wisata Pangsan yaitu menjadi tenaga kerja di homestay, menyediakan jasa transportasi menuju dan keluar dari homestay, dan juga ikut terlibat dalam aktivitas-aktivitas yang ditawarkan pihak homestay kepada wisatawan. Partisipasi tidak langsung yang dilakukan oleh masyarakat dalam mengembangkan homestay yaitu kegiatan gotong royong yang dilakukan masyarakat untuk menjaga kebersihan, keamanan, dan kenyamanan lingkungan. Warung-warung milik masyarakat yang ada di sekitar homestay secara tidak langsung juga membantu dalam pengembangan homestay. Kendala yang dihadapi oleh masyarakat dalam pengembangan homestay yaitu lemahnya promosi homestay, lemahnya permodalan dalam pengembangan homestay dan lemahnya kemampuan SDM masyarakat setempat.
\end{abstract}

Kata kunci: Desa Wisata Pangsan, Homestay, Persepsi Masyarakat, Partisipasi Masyarakat 


\section{Pendahuluan}

Jumlah wisatawan mancanegara ke Bali pada tahun 2017 mengalami peningkatan sebesar 15,62\% atau sebanyak 5,6 juta wisatawan dibandingkan dengan tahun sebelumnya yang mencapai 4,9 juta wisatawan (BPS, 2017). Jumlah wisatawan di tahun 2017 tersebut sudah memenuhi target kunjungan wisatawan mancanegara ke Bali untuk tahun 2020 yaitu sebanyak 5 juta wisatawan mancanegara seperti yang tercantum dalam Peraturan Daerah Provinsi Bali Nomor 10 Tahun 2015 tentang Rencana Induk Pembangunan Kepariwisataan Daerah Provinsi Bali Tahun 2015-2029. Meskipun tingkat kunjungan swisatawan sudah menunjukan trend yang positif, namun persebarannya belum merata ke seluruh destinasi yang ada di masing-masing kabupaten/kota di Provinsi Bali. Bahkan di Kabupaten Badung sendiri kunjungan wisatawan masih terpusat di wilayah Kabupaten Badung bagian selatan (Awirya dkk, 2017).

Pemerintah Kabupaten Badung dalam upaya melakukan pemerataan pariwisata dan juga meningkatkan kesejahteraan masyarakat pedesaan, telah menetapkan 11 Desa Wisata yang sebagian besar berada di wilayah Kabupaten Badung Utara yang dituangkan dalam Peraturan Bupati Badung Nomor 47 Tahun 2010 tentang Penetapan Kawasan Desa Wisata. Hal ini sejalan dengan Perda Kabupaten Badung Nomor 26 Tahun tentang Rencana Tata Ruang Wilayah Kabupaten Badung Tahun 2013 - 2033, dimana wilayah Kabupaten Badung Utara akan dikembangkan dengan fungsi utama sebagai kawasan konservasi dan pertanian terintegrasi yang salah satunya meliputi pengembangan daya tarik wisata berbasis Agrowisata dan Ekowisata.

Desa Wisata Pangsan adalah salah satu desa wisata yang ada di wilayah Kabupaten Badung Utara. Desa ini memiliki sumber daya alam berupa aset vista persawahan, perkebunan, Sungai Ayung, serta potensi budaya berupa suasana pedesaan, pola permukiman tradisional, bangunan keagamaan serta kesenian tradisional. Potensi alam dan budaya yang ada di Desa Wisata Pangsan berpeluang untuk dikembangkan menjadi daya tarik wisata yang menarik. Beberapa kegiatan yang dapat dilakukan oleh wisatawan di Desa Wisata Pangsan yaitu tracking, cycling, dan rafting. Selain itu kehidupan bermasyarakat dan tradisi budaya yang ada di Desa Pangsan dapat menjadi salah satu atraksi wisata yang akan memberikan pengalaman yang menarik bagi wisatawan yang berkunjung.

Meski memiliki berbagai potensi daya tarik, Desa Wisata Pangsan masih memiliki beberapa kekurangan, diantaranya lemahnya kualitas sumber daya manusia, belum optimalnya kerjasama dengan travel agent dan promosi, belum optimalnya pengembangan potensi daya tarik wisata, kurangnya sarana penunjang (akomodasi, tempat parkir, wc umum, pos jaga, dll), dan tidak adanya souvenir khas Desa Pangsan (Wikanatha, 2016). Salah satu hal penting dalam mengembangkan sebuah desa wisata adalah penyediaan pondok wisata (homestay) sebagai sarana akomodasi bagi wisatawan yang berkunjung. Menurut Peraturan Menteri Pariwisata dan Ekonomi Kreatif Republik Indonesia No. 9 Tahun 2014 tentang Standar Usaha Pondok Wisata, homestay adalah penyediaan akomodasi berupa bangunan rumah tinggal yang dihuni oleh pemiliknya dan dimanfaatkan sebagian untuk disewakan dengan memberikan kesempatan kepada wisatawan untuk berinteraksi dalam kehidupan sehari-hari pemiliknya. Ketersediaan homestay di Desa Wisata Pangsan akan memberikan 
kesempatan kepada wisatawan untuk menetap di desa dan menikmati potensi alam dan juga budaya yang dimiliki oleh desa dengan lebih maksimal. Selain itu, adanya wisatawan yang menetap di wilayah desa juga akan berdampak pada meningkatnya pendapatan ekonomi masyarakat di desa tersebut.

\section{Rumusan Masalah}

Berdasarkan latar belakang diatas, rumusan masalah dari penelitian ini adalah:

1) Bagaimana persepsi masyarakat lokal terhadap pengembangan homestay di Desa Wisata Pangsan?

2) Bagaimana partisipasi masyarakat dalam pengembangan homestay di Desa Wisata Pangsan?

3) Apa saja kendala yang ditemui oleh masyarakat dalam mengembangkan homestay di Desa Wisata Pangsan?

\section{Metode Penelitian}

Penelitian ini dilakukan di Desa Wisata Pangsan Kecamatan Petang Kabupaten Badung dengan objek penelitian bentuk partisipasi masyarakat local dalam pengembangan homestay. Penelitian ini menggunakan pendekatan kuantitatif dan kualitatif yang bersifat deskriptif dan preskriptif. Jenis penelitian ini adalah deskriptif dengan model penelitian studi kasus (case study). Tujuan penelitian deskriptif adalah untuk membuat deskripsi secara sistematis, faktual dan akurat mengenai fakta-fakta dan sifat-sifat populasi atau daerah tertentu. Fakta-fakta yang ingin diketahui adalah persepsi masyarakat terhadap keberadaan homestay, bentuk partisipasi masyarakat dalam pengembangan homestay, dan kendala yang dihadapi masyarakat dalam pengembangan homestay di Desa Wisata Pangsan.

Adapun metode analisis yang digunakan dalam penelitian ini antara lain:

1. Metode analisis deskriptif-kuantitatif yaitu analisis untuk mengelola dan menafsirkan data kuantitatif yang diperoleh sehingga dapat menggambarkan keadaan dan permasalahan yang sebenarnya pada obyek yang dikaji. Metode analisis ini digunakan untuk mendeskripsikan dan mengidentifikasi persepsi masyarakat Desa Pangsan terhadap keberadaan homestay di Desa Wisata Pangsan.

2. Metode analisis deskriptif-kualitatif yaitu analisis untuk mengelola dan menafsirkan data yang diperoleh dan mengelompokkannya sehingga dapat menggambarkan keadaan dan permasalahan yang sebenarnya pada obyek yang dikaji. Metode analisis ini digunakan untuk mendeskripsikan dan mengidentifikasi bentuk partisipasi yang dilakukan oleh masyarakat local dalam pengembangan homestay di Desa Wisata Pangsan dan kendala yang dihadapi masyarakat dalam pengembangan homestay. 


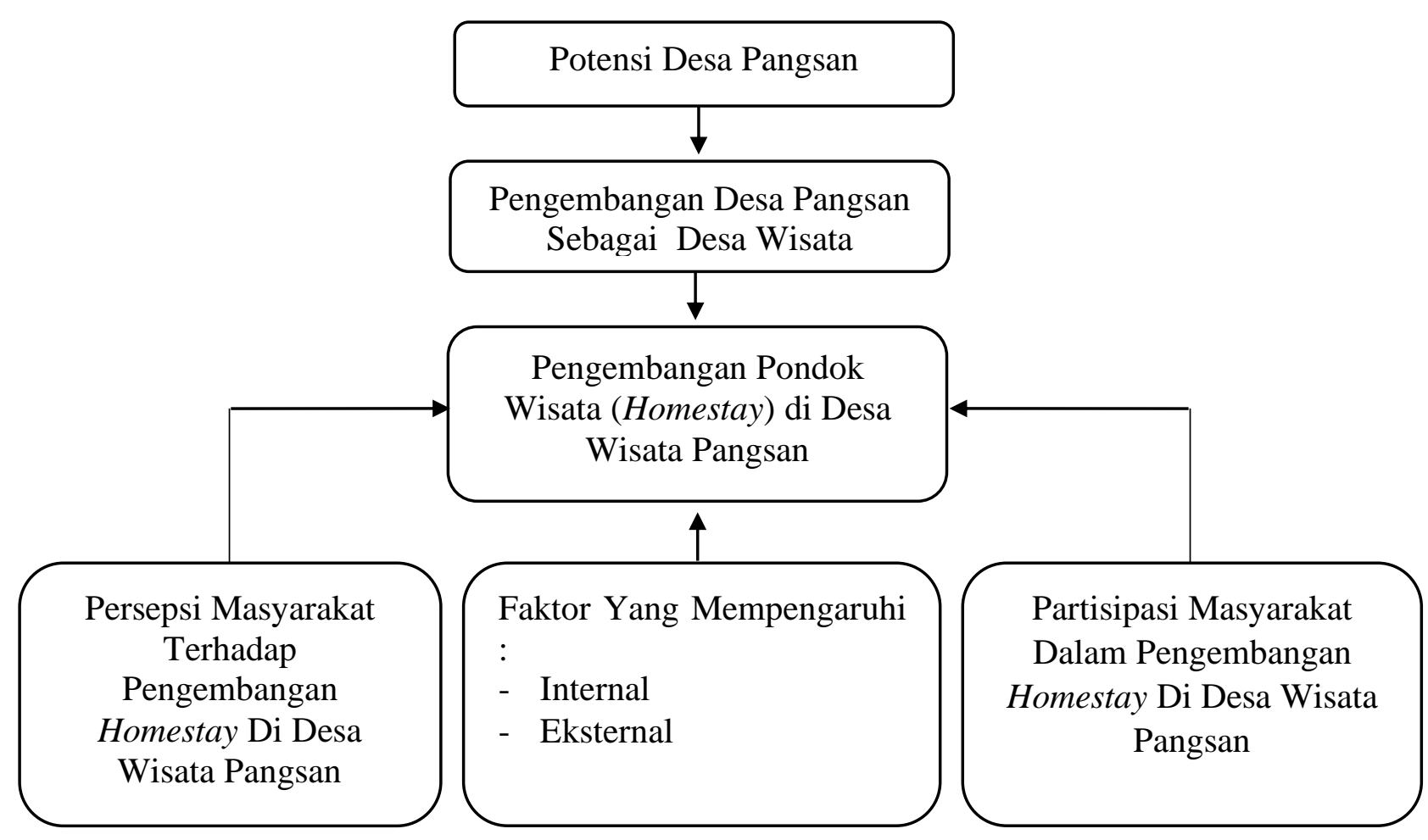

\section{Gambar 1}

Kerangka Analisis

\section{Hasil dan Pembahasan}

\subsection{Persepsi Masyarakat terhadap Pengembangan Homestay}

Dengan berkembangnya usaha homestay di Desa Wisata Pangsan, maka interaksi antara wisatawan dengan masyarakat lokal akan lebih sering terjadi dikarenakan wisatawan yang menginap selama beberapa hari. Meskipun masyarakat local belum banyak yang kurang ataupun tidak mengerti mengenai pariwisata, tetapi mereka sangat senang dengan kedatangan wisatawan, dan saat mereka diajak untuk terlibat dalam kegiatan bersama wisatawan, mereka mau menurut (Nyoman Kitha, 2019). Teori irridex (irritation index) yang dicetuskan oleh Doxey (1975) menggambarkan tahapan-tahapan perubahan sikap masyarakat lokal terhadap wisatawan. Tahapan-tahapan tersebut yang dimulai dari Euphoria, Apathy, Annoyance, dan Antagonism menggambarkan bagaimana perubahan sikap masyarakat lokal terhadap wisatawan yang pada awalnya positif kemudian berubah menjadi semakin negatif. Hal ini berkaitan dengan bisnis homestay yang dikembangkan di wilayah desa sebagai sarana bagi wisatawan untuk menginap dan mengamati bagaimana kehidupan keseharian masyarakat lokal. Untuk mengetahui posisi tahapan persepsi yang dialami masyarakat saat ini terhadap pengembangan homestay di Desa Wisata Pangsan, penulis melakukan wawancara dengan masyarakat lokal sebanyak 20 orang yang berasal dari empat Banjar Dinas di Desa tersebut. Hasil dari wawancara mengenai persepsi masyarakat dijabarkan dalam tabel berikut. 
Tabel 1

Persepsi Masyarakat Terhadap Pengembangan Homestay

\begin{tabular}{|c|c|c|c|c|c|}
\hline No. & Pertanyaan & $\mathbf{Y a}$ & $\%$ & Tidak & $\%$ \\
\hline 1 & $\begin{array}{l}\text { Apakah Bapak/Ibu tahu bahwa Desa Pangsan } \\
\text { merupakan sebuah Desa Wisata? }\end{array}$ & 20 & 100 & 0 & 0 \\
\hline 2 & $\begin{array}{l}\text { Apakah Bapak/Ibu senang dengan } \\
\text { perkembangan Pariwisata di Desa Wisata } \\
\text { Pangsan? }\end{array}$ & 20 & 100 & 0 & 0 \\
\hline 3 & $\begin{array}{l}\text { Apakah Bapak/Ibu tertarik untuk terlibat terlibat } \\
\text { dalam aktivitas pariwisata di Desa? }\end{array}$ & 15 & 75 & 5 & 25 \\
\hline 4 & $\begin{array}{l}\text { Apakah Bapak/Ibu senang dengan kedatangan } \\
\text { wisatawan ke Desa ini? }\end{array}$ & 20 & 100 & 0 & 0 \\
\hline 5 & $\begin{array}{l}\text { Apakah kedatangan wisatawan ke Desa } \\
\text { mengganggu aktivitas keseharian Bapak/Ibu? }\end{array}$ & 0 & 0 & 20 & 100 \\
\hline 6 & $\begin{array}{l}\text { Apakah Bapak/Ibu setuju jika ada wisatawan } \\
\text { yang ikut dalam kegiatan keseharian yang } \\
\text { dilakukan? }\end{array}$ & 20 & 100 & 0 & 0 \\
\hline 7 & $\begin{array}{l}\text { Apakah Bapak/Ibu mengetahui bahwa di Desa } \\
\text { Wisata Pangsan terdapat penginapan untuk } \\
\text { wisatawan yang berkunjung? }\end{array}$ & 20 & 100 & 0 & 0 \\
\hline 8 & $\begin{array}{l}\text { Apakah Bapak/Ibu senang dengan adanya } \\
\text { homestay atau penginapan di Desa Wisata } \\
\text { Pangsan? }\end{array}$ & 20 & 100 & 0 & 0 \\
\hline 9 & $\begin{array}{l}\text { Apakah Bapak/Ibu tertarik untuk mendirikan } \\
\text { usaha homestay atau penginapan milik sendiri? }\end{array}$ & 17 & 85 & 3 & 15 \\
\hline 10 & $\begin{array}{l}\text { Apakah Bapak/Ibu tertarik untuk mengikuti } \\
\text { pelatihan terkait Pariwisata? }\end{array}$ & 17 & 85 & 3 & 15 \\
\hline
\end{tabular}

Berdasarkan tabel di atas yang didapatkan melalui wawancara dengan 20 orang masyarakat, seluruh responden sudah mengetahui bahwa Desa Pangsan merupakan sebuah Desa Wisata dan mereka senang dengan perkembangan pariwisata di Desa saat ini. Untuk ikut terlibat dalam kegiatan Pariwisata yang ada di desa, sebanyak $75 \%$ dari responden tertarik untuk terlibat untuk mendapatkan pengalaman dan penghasilan tambahan. Sedangkan $15 \%$ responden lainnya tidak tertarik untuk terlibat karena merasa kemampuannya kurang. Seluruh responden merasa senang dengan kedatangan wisatawan, hal tersebut dikarenakan sejauh ini wisatawan yang pernah berkunjung ke desa sangat ramah dan dan tidak mengganggu kegiatan keserahian yang dilakukan oleh masyarakat. Para responden juga tidak keberatan jika ada wisatawan yang ikut terlibat dalam kegiatan keseharian selama tidak mengganggu dan merugikan masyarakat. 
Terkait dengan keberadaan homestay di Desa Pangsan, seluruh responden mengetahui keberadaan homestay yang bernama Pondok Wisata Campuhan Hilltop tersebut karena mereka mengenal pemilik dari homestay tersebut. Pemahaman masyarakat lokal tentang homestay masih terbatas sebagai tempat menginap bagi wisatawan yang berkunjung. Seluruh responden merasa senang dengan keberadaan homestay tersebut karena dianggap membuka lapangan pekerjaan baru bagi masyarakat setempat. Tidak jarang pemilik homestay menggunakan jasa masyarakat setempat untuk membantu pada saat ada wisatawan yang datang untuk menginap.

Dampak lain dari keberadaan homestay yang sudah ada saat ini adalah adanya keinginan masyarakat local untuk membangun/memiliki homestay. Tercatat ada sebanyak 85\% responden tertarik untuk mendirikan usaha homestay mereka sendiri dengan alasan untuk mendapatkan penghasilan tambahan, sedangkan sedangkan $15 \%$ responden lainnya tidak tertarik karena merasa takut tidak dapat mengerti apa teknis pengelolaan homestay dan juga merasa tidak percaya diri karena tidak memiliki kemampauan bahasa yang baik. Lemahnya kemampuan pengelolaan dan kemampuan berbahasa asing yang baik menyebaban masyarakat local tertarik dengan adanya program peningkatan kapasitas SDM. Ini terlihat dari jumlah responden yang tertarik untuk mengikuti program pelatihan kepariwisataan yaitu sebanyak $85 \%$.

Berdasarkan hasil wawancara dengan pengelola homestay dan Kelompok Sadar Wisata (Pokdarwis) usaha homestay yang sudah ada di Desa Wisata Pangsan saat ini memberikan dampak positif secara ekonomi bagimasyarakat yang ikut terlibat baik secara langsung maupun tidak langsung. Hal tersebut dikarenakan pengelola homestay yang ada di wilayah desa menggunakan masyarakat lokal sebagai tenaga kerja. Selain itu dengan adanya wisatawan yang menginap di desa, maka usaha-usaha lainnya seperti pengerajin dan warungwarung yang ada di wilayah desa juga merasakan dampak yang positif.

Berdasarkan hasil penelitian tersebut, dapat disimpulkan bahwa saat ini masyarakat lokal di Desa Wisata Pangsan berada pada tahap Euphoria yaitu tahap dimana perkembangan pariwisata, usaha homestay, dan kedatangan wisatawan diterima dengan baik dengan harapan akan memajukan perekonomian masyarakat lokal di Desa Wisata Pangsan untuk kedepannya.

\subsection{Partisipasi Masyarakat dalam Pengembangan Homestay}

Partisipasi masyarakat menurut Mulyadi (2009) dibedakan menjadi dua yaitu partisipasi langsung dan partisipasi tidak langsung. Partisipasi langsung dapat berupa pembangunan secara gotong royong, keterlibatan dalam pengusaha pariwisata atau pembinaan untuk menumbuhkan rasa ikut memiliki di kalangan masyarakat oleh pemerintah. Sedangkan bentuk partisipasi tidak langsung meliputi pemeliharaan kebersihan lingkungan, pembinaan seni budaya yang bermutu, pembinaan keindahan, dan pembinaan kepribadian.

Saat ini hanya ada satu homestay di Desa Wisata Pangsan. Hal tersebut dikarenakan Desa Wisata Pangsan masih dalam pengembangan sehingga partisipasi yang dilakukan oleh masyarakat juga masih sangat terbatas. Partisipasi masyarakat di Desa Wisata Pangsan secara langsung dan tidak langsung dalam pengembangan homestay adalah sebagai berikut. 


\section{1) Partisipasi Langsung}

Berdasarkan hasil wawancara yang telah dilakukan, beberapa masyarakat ikut berpartisipasi sebagai tenaga kerja di homestay tersebut. Pemilik homestay yang dikenal dengan nama Pondok Wisata Campuhan Hilltop mengatakan bahwa homestay tersebut menggunakan masyarakat lokal sebagai tenaga kerja dikarenakan ingin membantu meningkatkan perekonomian masyarakat sekitar. Dengan mengajak masyarakat sekitar untuk menjadi tenaga kerja, homestay tersebut mendapatkan dukungan dari masyarakat sekitar karena memberikan keuntungan bagi seluruh pihak.

Selain sebagai tenaga kerja, masyarakat juga dilibatkan dalam aktivitas trekking, cycling, maupun village tour yang ditawarkan oleh pemilik homestay. Masyarakat yang berpartisipasi dalam berbagai aktivitas yang ditawarkan oleh pemilik homestay biasanya mendapatkan tugasnya masing-masing. Masyarakat yang berpartisipasi ada yang mendapatkan tugas untuk menyambut wisatawan dengan gamelan, menyediakan makanan tradisional, membuat berbagai macam kerajinan dari janur, dan juga sebagai pendamping selama trekking, cycling, ataupun village tour. Namun tidak jarang partisipasi masyarakat hanya sebatas mengantarkan wisatawan yang sedang mencari lokasi homestay jika tidak ada kegiatan village tour dari rombongan wisatawan yang sedang berlangsung.

\section{2) Partisipasi Tidak Langsung}

Partisipasi tidak langsung adalah partisipasi yang dilakukan secara tidak langsung bersentuhan dengan kegiatan pariwisata dimana masyarakat secara individu tidak langsung melukan kontribusi dalam kegiatan pariwisata. Dalam membantu pengembangan homestay di Desa Wisata Pangsan, terdapat beberapa aktivitas yang dilakukan oleh masyarakat yang secara tidak langsung membantu dalam pengembangan homestay tersebut. Beberapa hal tersebut seperti kegiatan masyarakat dalam gotong royong untuk menjaga kebersihan desa, menjaga keamanan desa, membuat akses yang lebih baik, serta membangun fasilitasfasilitas umum. Kegiatan-kegiatan tersebut sebenarnya dilakukan masyarakat untuk menciptakan lingkungan desa yang lebih baik bagi mereka, namun hal tersebut juga secara tidak langsung memberikan rasa aman dan nyaman bagi wisatawan selama menginap di homestay yang ada di wilayah desa dan berinteraksi dengan masyarakat lokal.

Partisipasi masyarakat secara tidak langsung seperti melakukan gotong royong rutin dilakukan oleh seluruh masyarakat desa setiap satu minggu sekali. Hal tersebut dilakukan agar lingkungan desa tetap terjaga kebersihannya. Meski kegiatan tersebut merupakan suatu hal yang biasa, namun hal ini dapat menjadi atraksi yang menarik bagi wisatawan. Hal tersebut dikarenakan wisatawan yang berkunjung ke Desa Wisata Pangsan ingin melihat bagaimana tradisi serta kehidupan sehari-hari dari masyarakat yang ada di Desa.

Warung-warung milik masyarakat yang ada di sekitar homestay juga secara tidak langsung ikut berpartisipasi dalam pengembangan homestay. Hal tersebut 
dikarenakan warung-warung kecil tersebut merupakan salah satu daya tarik bagi wisatawan yang berkunjung dan mereka biasanya akan datang dan mencoba berbagai makanan khas atau tradisional yang dijual di warung-warung tersebut.

\subsection{Kendala yang Dihadapi Masyarakat dalam Pengembangan Homestay}

Dalam mengembangkan homestay di Desa Wisata Pangsan, baik dari pihak pengelola homestay dan juga masyarakat lokal memiliki beberapa kendala yang menghambat mereka. Berdasarkan hasil wawancara dengan pengelola Pondok Wisata Campuhan Hilltop, kendala yang dihadapi dalam mengembangkan homestay yang dikelola saat ini yaitu pada bagian promosi. Pengelola Pondok Wisata Campuhan Hilltop, Ibu Nyoman Sarni, menyampaikan bahwa saat ini homestay miliknya belum melakukan promosi secara online karena berbagai keterbatasan baik secara fasilitas maupun kemampuan.

Kendala yang juga dihadapi oleh masyarakat local yang belum memiliki homestay. Berdasarkan pembahasan pada bagian persepsi, ditemukan ada $85 \%$ responden berkeinginan untuk mendirikan/membuat homestay, setelah merasakan secara langsung dampak dari adanya aktifitas wisata di Desa Wisata Pangsan. Namun mereka merasa tidak percaya diri untuk membangun homestay karena adanya keterbatasan modal dan lemahnya kemampuan pengelolaan homestay dan kemampuan berbahasa asing.

\section{Kesimpulan dan Saran}

\subsection{Kesimpulan}

Berdasarkan hasil pembahasan diatas, maka dapat diambil beberapa kesimpulan seperti berikut:

1) Posisi tahapan persepsi masyarakat lokal terhadap pengembangan homestay dan juga terhadap wisatawan saat ini yaitu berada pada tahap Euphoria. Tahap Euphoria berarti masyarakat senang dengan dikembangkannya homestay di desa mereka serta menyambut dengan baik wisatawan yang datang untuk berkunjung dan menginap.

2) Masyarakat tertarik untuk mendirikan usaha homestay milik mereka sendiri. Menurut perwakilan Pokdarwis pengembangan homestay lainnya juga perlu agar wisatawan dapat memiliki alternatif pilihan homestay yang ingin mereka tempati.

3) Bentuk partisipasi masyarakat dalam mengembangkan homestay di Desa Wisata Pangsan dikelompokan menjadi partisipasi langsung dan partisipasi tidak langsung. Partisipasi langsung yang dilakukan oleh masyarakat dalam pengembangan homestay yaitu menjadi tenaga kerja di homestay, mengantarkan wisatawan menuju homestay, serta ikut terlibat dengan tugasnya masing-masing dalam kegiatan wisata yang ditawarkan oleh pihak homestay kepada wisatawan. Sedangkan partisipasi tidak langsung yang dilakukan oleh masyarakat meliputi menjaga kebersihan dan keamanan lingkungan desa serta membangun berbagai fasilitas umum. Hal tersebut mengakibatkan wisatawan yang berkunjung dan menginap di desa merasa aman dan nyaman. 
4) Kendala yang dihadapi oleh masyarakat dalam pengembangan homestay di Desa Wisata Pangsan saat ini adalah promosi yang kurang dan juga modal serta pengetahuan masyarakat yang tertarik untuk mendirikan usaha homestay milik mereka sendiri.

\subsection{Saran}

Berdasarkan penelitian yang telah dilakukan, penulis dapat memberikan saran kepada pihak-pihak yang diharapkan dapat membantu pengembangan Desa Wisata Pangsan agar dapat lebih baik kedepannya, yaitu sebagai berikut:

1) Kepada Masyarakat Desa Wisata Pangsan

Diharapkan dapat terus menjaga dan melestarikan alam serta tradisi budaya yang ada di Desa Wisata Pangsan. Selain itu masyarakat juga harus terus meningkatkan kemampuannya agar dapat berpartisipasi dengan lebih baik lagi dalam mengembangkan Desa Wisata Pangsan.

2) Kepada Pemerintah

Diharapkan Pemerintah dapat membantu pembangunan sarana dan prasarana pendukung pariwisata yang ada di Desa Wisata Pangsan serta dapat segera memberikan pelatihan dan pendampingan guna meningkatkan kualitas sumber daya manusia yang ada di Desa Wisata Pangsan. Selain itu juga Pemerintah diharapkan dapat membantu dalam mendatangkan sejumlah wisatawan ke Desa Wisata Pangsan agar kegiatan pariwisata di desa tersebut dapat terus berjalan dengan baik.

\section{DAFTAR PUSTKA}

Amdani, Suut. 2008. Analisis Potensi Obyek Wisata Alam Pantai di Kabupaten Gunung Kidul. Skripsi. Surakarta: Fakultas Geografi UMS.

Asdep Pengembangan SDM Pariwisata dan Hubungan Antar Lembaga Kementrian Pariwisata RI. 2019. Buku Panduan Pengembangan Desa Wisata Berbasis Pendampingan Melalui Perguruan Tinggi. Jakarta.

Awirya Agni, Stephanie Gunawan, dan Putriana Norman. (2017). Upaya Pemerataan Kontribusi Pariwisata Pada Perekonomian Bali. Jurnal Riset Manajemen dan Bisnis (JRMB) Fakultas Ekonomi UNIAT, II(3).

Badan Pusat Statistik Provinsi Bali. 2017. Jumlah Hotel Bintang di Bali Menurut Kabupaten/Kota dan Kelas 2000 - 2017. Denpasar

Badan Pusat Statistik Provinsi Bali. 2017. Jumlah Wisatawan Mancanegara Ke Bali.

Bupati Badung. 2010. Peraturan Bupati Badung Nomor 47 tentang Penetapan Kawasan Desa Wisata di Kabupaten Badung. Lembaran Daerag Kabupaten Badung Nomor 44. Sekretaris Daerah

Bupati Badung. 2013. Peraturan Daerah Kabupaten Badung Nomor 26 tentang Rencana Tata Ruang Wilayah Kabupaten Badung Tahun 2013 - 2033. Berita Daerah Kabupaten Badung Nomor 25. Sekretaris Daerah 
Doxey, G. V. 1975. A Causation Theory of Visitor-Resident Irritants: Methodology and Research Inference. Paper Presented At The TTRA Conference, San Diego, California, pp. 195 - 198.

Maharini, dan Arida. 2014. Keterlibatan Masyarakat Dalam Mengelola Desa Wisata Pangsan Di Kabupaten Badung. Jurnal Destinasi Pariwisata, II (1).

Melis. 2016. Analisis Partisipasi Masyarakat Dalam Pembangunan Desa Studi Di Desa Wawolesea Kecamatan Lasolo Kabupaten Konawe Utara. Skripsi. Kendari: Fakultas Ekonomi Dan Bisnis Universitas Halu Oleo.

Mertha, dan Pitanatri. 2018. Homestay Mozaik Pariwisata Berbasis Kerakyatan. Bali: STP Nusa Dua.

Miles, Huberman. 1984. Analisis Data Kualitatif Buku Sumber Tentang Metode-metode Baru. Jakarta: UIP.

Mulyadi, Mohammad. 2009. Partisipasi Masyarakat Dalam Pembangunan Masyarakat Desa. Jakarta: Nadi Pustaka.

Nazir, Moh, 1988. Metode Penelitian. Jakarta: Ghalia Indonesia.

Ointoe, Reiner Emyot, et.al. 2005. Menciptakan Gagasan, Mendorong Gerakan (Pengalaman Mendorong Partisipasi Publik). Manado: Yayasan SERAT.

Pantiyasa, I. Wayan; Sutiarso, Moh Agus; Suprapto, I. Nyoman Arto. 2020. PENINGKATAN POTENSI MASYARAKAT DALAM PENGEMBANGAN DESTINASI "PELAGA AGROTOURISM PARK” MELALUI PROGRAM PENDAMPINGAN DESA MITRA DI DESA PELAGA KABUPATEN BADUNG, BALI. JPM17: Jurnal Pengabdian Masyarakat. 5(01): 07-12.

Pantiyasa, I. Wayan; Sutiarso, Moh Agus; Suprapto, I. Nyoman Arto. 2021. Peningkatan Daya Saing UKM Kopi Sebagai Produk Penunjang Pelaga Agrotourism Park. Jurnal Abdi Masyarakat. 1(1): 30-35

Pemerintah Indonesia. 2009. Undang - Undang No. 10 Tahun 2009 Tentang Kepariwisataan. Lembaran Negara Republik Indonesia Nomor 11. Sekretaris Negera

Robbins, S. P. 2001. Perilaku Organisasi: Konsep, Kontroversi,Aplikasi. Jakarta: PT. Prenhallindo.

Sugiarto, dkk. 2015. Metodologi Penelitian Hospitaliti \& Pariwisata. Tangerang: PT. Matana Publishing Utama.

Sugiyono, 2016. Metode Penelitian Kuantitatif, Kualitatif, dan R\&D. Bandung: Alfabeta.

Suprapto, Nyoman Arto. (2010). Arahan Pengendalian Pembangunan Kawasan Cagar Budaya Candi Tebing Gunung Kawi Tampak Siring Kabupaten Gianyar. Tugas Akhir Program Studi Perencanaan Wilayah dan Kota Institut Teknologi Sepuluh November Surabaya.

Suprapto, Nyoman Arto; Osawa, Takahiro; Putra, I Dewa Nyoman Nurweda. 2018. Estimation of Green Land to Urban Change Based on Cellular Automata (CA) Method in Singaraja City and its Surrounding Areas. International Journal of Environment and Geosciences. 2(1): 1-8

Suprapto, Nyoman Arto dan Suryanto, Agus. 2019. Partisipasi Masyarakat dalam Pengembangan Homestay di Desa Wisata Pangsan Kabupaten Badung. Proceeding Seminar Riset Terapan Hospitality dan Kepariwisataan Indonesia 2019, Nusa Dua: 11 Juli 2019: Hal. 425 - 433

Suprapto, Nyoman Arto. (2019). SPATIAL SIMULATION BASED ON GEOGRAPHIC INFORMATION SYSTEM (GIS) AND CELLULAR AUTOMATA (CA) FOR LAND USE CHANGE MODELING IN SINGARAJA CITY AND ITS SURROUNDING AREA. Tesis Program Magister Ilmu Lingkungan Universitas Udayana. 
Yoeti, O. A. 2002. Perencanaan dan Pengembangan Pariwisata. Jakarta: PT Pradnya Paramita.

Wikanatha. 2016. Strategi Pengembangan Desa Pangsan Sebagai Desa Wisata Di Kecamatan Petang Kabupaten Badung.

https://www.researchgate.net/profile/Putu Agus Sagita/publication/322927258 Strat egi_Pengembangan_Desa_Pangsan_sebagai_Desa_Wisata_di_Kecamatan_Petang_Ka bupaten Badung/links/5a77668c45851541ce5a60aa/Strategi-Pengembangan-DesaPangsan-sebagai-Desa-Wisata-di-Kecamatan-Petang-Kabupaten-Badung.pdf. (Diakses 22 September 2018) 